University of Nebraska - Lincoln

DigitalCommons@University of Nebraska - Lincoln

Journal for the Advancement of Developing

Economies

Economics Department

2016

\title{
Challenges of Respecting Riparian Rights Around Hydroelectric Dams in Cameroon Since 1949
}

Séverin Nwaha

University of Buea

Follow this and additional works at: https://digitalcommons.unl.edu/jade

Part of the Econometrics Commons, Growth and Development Commons, International Economics Commons, Political Economy Commons, Public Economics Commons, and the Regional Economics Commons

Nwaha, Séverin, "Challenges of Respecting Riparian Rights Around Hydroelectric Dams in Cameroon Since 1949" (2016). Journal for the Advancement of Developing Economies. 9.

https://digitalcommons.unl.edu/jade/9

This Article is brought to you for free and open access by the Economics Department at DigitalCommons@University of Nebraska - Lincoln. It has been accepted for inclusion in Journal for the Advancement of Developing Economies by an authorized administrator of DigitalCommons@University of Nebraska - Lincoln. 


\title{
Challenges of Respecting Riparian Rights Around Hydroelectric Dams in Cameroon Since 1949
}

\author{
Séverin Nwaha \\ University of Buea, Cameroon
}

\begin{abstract}
The impact of electric energy on socio-economic development has attracted the attention of all categories of people in society. This is because of the role power plays in the economic and industrial sectors of any country. Public authorities seem to be more concerned with protecting capitalist interests at the detriment of the riparian population. Despite regulations and legal provisions, authorities are still not able to implement a rigorous policy in this sector in Cameroon due to administrative bottle necks, among other factors. Furthermore, the existence of multiple regulatory and management bodies creates confusion. Legislation related to this issue is usually not taken seriously; hence implementation in many cases does not follow an ordinary and normal procedure. In fact, it is clear that the Cameroonian consumer, and especially riparian populations around power generation sources, are not protected.
\end{abstract}

Keywords: Law, Hydroelectric dams, Riparian Populations, Development, Environment.

\section{INTRODUCTION}

Several power sources are known and exploited across the world in order to meet the energy needs of the population. These include thermal, wind, solar, nuclear, and hydroelectric energy. Hydroelectric energy is the energy generated by converting the pressure of falling or running water to electricity by means of a turbine coupled to a generator. ${ }^{1}$ It is created by dams which are barriers of concrete or earth that are built across rivers, and which control the flow of water. ${ }^{2}$ The term "riparian" refers to an owner of land along a river, or a population situated along a riverbank or near a river. ${ }^{3}$ However, the first three forms (thermal, wind, and solar), are known as pollution-free energy due to their low percentage in environment destruction, according to the Objectives of Millennium (OM) on nature management and protection. But these power sources are limited in terms of capacity and production costs, which are exorbitant. Therefore, the use of nuclear energy is inevitable. Nuclear power is a subject of controversy between underdeveloped and developed countries because the latter always assume that nuclear energy is used by underdeveloped countries as a means of acquiring nuclear weapons, even if it is used for civilian purposes. Countries like Pakistan, Iran, and North Korea have been highly criticized in the manufacturing and development of nuclear plants. Consequently, the most reliable means of getting energy supply for poor countries remains hydroelectricity. This is in spite of the requirement of a watercourse with a significant flow rate to construct hydroelectric dams without too much risk as far as profit is concerned. However,

\footnotetext{
${ }^{1}$ Encarta Dictionaries, Electronic version.

${ }^{2}$ Ibid

${ }^{3}$ Ibid
} 
taking into account both the population and industrial growth, as well as climate change observed over the past few decades, water itself has become a more and more valuable and scarce asset which needs to be preserved. Thus, the construction of hydroelectric dams has become an expensive and elusive venture. Is it really possible to invest in this sector without damaging immediate and distant biodiversity? Taking into consideration the aforementioned factors, are investors and public authorities perhaps taking too much risk by sacrificing residents to selfish capitalist and egocentric interests? Are they really preserving riparian rights around the hydroelectric dams? Are these rights well identified and known by all stakeholders? To answer to all these questions, this study addresses the duties and rights of the riparian population around the hydroelectric dams in Cameroon since the construction of the first one in Edea, in 1949. The purpose of this research is to identify, define, clarify and understand the rights of all stakeholders in riparian areas. These, and other questions are addressed in detail in this paper which analyses existing documents on this subject.

\section{VARIOUS STAKEHOLDERS IN THE CONSTRUCTION AND EXPLOITATION PROCESS OF HYDROELECTRIC DAMS IN CAMEROON}

\section{Literature Review}

Since the 1970s, the international community has gradually started to be aware of the dangers threatening the environment. This explains why the World Heritage Centre has undertaken to regulate some activities related to wildlife through the Washington Convention (1973), and through Tenets 11 of the World Charter for Nature (1982). In the same vein, a conference was organized in Rio de Janeiro, Brazil, on 05 June, 1992, leading to the signing of a convention on biological diversity. This convention aimed at, among other things, preserving biodiversity, sustainable exploitation of biologically diverse resource areas, as well as a fair and equitable sharing of benefits from the exploitation of natural resources.

In Africa, from the Bamako Convention in Mali in 1991, through the Maputo Convention in Mozambique in 2003, to the African Convention on Nature Conservation and Natural Resources Management, focus has been on environmental protection, conservation and sustainability. These conventions also highlighted the sovereign right of states on issues related to the sustainable management of their natural resources for their own development.

In Cameroon, issues related to environmental preservation and protection have been given special attention by development actors and the three institutional powers of public life since 1996. Therefore, Law No 96/12 of 5 August, 1996, on the management of the environment was adopted by the National Assembly of Cameroon. This Law is accompanied by several decrees and orders of implementations, the first being Decree No 2005/0577/PM of 23 February, 2005, laying down modalities for realizing environmental impact assessments. Within the framework of the environmental impact study on underwater landscape, there is also Law No 98-005 of 14 April, 1998 to lay down conditions, in respect to environmental management and public health protection principles, within the general legal framework of water regimes. Government institutions in charge of monitoring compliance with regulation pertaining to underwater natural resources preservation and protection in Cameroon include the Ministry of Water Sources and Energy (MINEE) and Ministry of Environment and Wild Species Protection (MINEPED).

There is no need to demonstrate the social and economic significance of a power generation project, 
considering that many more people in the rural and urban areas need electricity. In spite of this, environmental impact studies are expected to limit the major adverse effects of this activity on the environment. ${ }^{4}$

Is it true that some investments always go with many risks and damages to the immediate environment, and sometimes distant ones? The construction and exploitation of hydroelectric dams affect both aquatic and terrestrial ecosystems, upstream as well as downstream, making previous residents victims of the development. ${ }^{5}$ One is therefore tempted to talk of, "development against its own promoter," that is, humans. ${ }^{6}$ As a matter of fact, Amin, Faire and Malkin (1977) are trying to answer the question concerning the future possibilities and future roles of various types of African industries. They are analyzing various feasible industrialization hypotheses, according to the evolution of the international division of labor, the creation of a new labor divisions, and the planned adoption of self-oriented national strategies requiring external relations reorganization.

But they are not the only scholars taking interest in this issue. Abdelmalki and Mundler (1995), have discussed theories of development, taking into account their own contributions and limitations. ${ }^{7}$ The originality of the approach is featured in the structure of the book, which is divided into three parts. The first part, "Development in question" assesses the current body of work, and introduces the second part which deals with "Development in action"; which enlightens us on the authors' former experiences and opens the reader's mind on the third and last part "Development in the future." This last part deals with the analysis of the current problem of developing riparian communities and infrastructure on the basis of short, medium or long term plans and promises. After presenting traditional theories which come along with the birth of developed economics, these authors presented motives of developmental economics. New problems with institutions, democracy, and environment were also highlighted, which gave a new definition to the concept of development. These three parts of development which seem to be deeply linked up are in fact not really cohesive, creating uncertainty in Africa's future as far as this development is concerned.

Mbonji Edjenguélé (1988) talks of the development process and defines it as: "a simple dynamism, a spring that drives something and makes it move from stage A to stage B." 8 To this effect, development will be considered as a process of climbing stairs from the base which would be point A to the summit which is represented by point B. Abdelmaki and Mundler (1995), for their part, are of the opinion that "to develop, major risks must always be taken, making victims who are most of the time riparian populations near the project to be carried out, for the interest of the majority."9This style of decision making follows a two-step path as mentioned above; namely, debate on this issue, and taking action in line with progress.

\footnotetext{
${ }^{4}$ Abstract of the WDC report, (2000), Dams and Development: an Overview, p. 30.

${ }^{5}$ Sadler, B., Verocai, I., and Vanclay, F., (2000), Environmental and Social Impact Assessment for Large Dams, thematic study V.2 of the WDC, p. 11.

${ }^{6}$ Amin, S., Faire, A., et Malkin, D., (1977), L'industrialisation et l'avenir de l'Afrique, Document préparé pour la Conférence Panafricaine sur les Stratégies pour le Futur de l'Afrique, Dakar, p. 17.

${ }^{7}$ Abdelmalki L., et Mundler, P., (1995), Economie du développement, Paris, Hachette Supérieur, p. 36.

${ }^{8}$ Mbonji Edjenguèlè, (1988), Les cultures de développement en Afrique : Essai sur l'impossible développement sans révolution culturelle, Yaoundé, Osiris-Africa, p. 8.

${ }^{9}$ L. Abdelmalki, Economie du développement, pp. 36-37
} 
The artificial barriers known as hydroelectric dams will not only constitute an obstacle to water ways, but will also significantly obstruct the continuity of riparian's daily activities. There is therefore conflict between the riparian populations, who are always against being separated from what belongs to them (the land of their ancestors and the site of their activities), and the capitalist investors who most often seek at all costs to gain a return from their investment. This tense atmosphere often partly affects the regulatory bureaucracy, which generally prefers not take any decision in an attempt to please all stakeholders involved, but usually ends up displeasing one of the partners, usually the riparian population. In many cases, the State, in taking into consideration national or majority interests, sacrifices riparian populations in favor of development. Therefore, what was regarded yesterday as charity, and as a source of endogenous development, suddenly turns into a nightmare of a frustrated group, and victims of a project carried out in the guise of national interests, which are usually a façade for private interests. In this case, the project pushes the people away, and further restricts any activities that can contribute to the sustainable livelihood of the population so displaced because of the project. ${ }^{10}$

Such a situation often leads to serious ill-will, terror, rejection, confusion, and resentment between the victims and beneficiaries of a project. To prevent all of this from happening, it is absolutely necessary to identify various rights and duties of each party involved in the construction or management and exploitation of hydroelectric dams and have them make firm commitments under threat of penalty in the event of non-fulfilment by the arbitrator-State. There are always stakeholders playing different roles in projects of this nature.

\section{Various Stakeholders}

In an investment policy, different stakeholders are comprised of capital investors, riparian communities, and/or landowners of the project site and affected areas along the river. The State is usually the arbitrator to ensure compliance by everyone in terms of standards and commitments. Even when the investor is the State, it still keeps its position as arbitrator. With the world becoming increasingly capitalist, the first stakeholders (investors) usually consist of individual and collective businessmen who take the risk of investing their capital to make a profit. The benefit so derived is regarded as the reward of the risk taken by investing their money in businesses. ${ }^{11}$

Generally, the motivation here remains the profit to be generated as a result of the project, regardless of the consequences on the environment and riparian populations. Financial capital alone is insufficient for realizing investors' projects, because the capital should be invested in a safe place which is suitable for the defined project, but generally, this site is not their land; it therefore becomes imperative to acquire the land by involving a second stakeholder, generally made up of landowners and/or riparian communities of the site. In principle, the latter should be partial shareholders after estimating the relative value of their capital in the project site. Unfortunately, this heritage is often acquired at a lower cost, either by being bought cheaply, or granted free of charge on behalf of the population, with the expectation of future community development. Given the complexity of land ownership, specifically in sub-Saharan Africa, land is a matter of community and not individuals, as once explained by a patriarch: "In Black Africa in general, and within Bantu people specifically,

\footnotetext{
${ }^{10}$ Adams, W., (2000), The Social Impacts of Large Dams: Equity and Distributional Issues, thematic study I.1 of the WDC, p. 111.

${ }^{11}$ Wiehen, M.H., and Transparency International, (1999), Transparency and Corruption on Building Large Dams, article prepared for the thematic study V.4 p. 123.
} 
land is and remains the community property. It is recognized by the customary law. This community is often defined by blood ties or lineage. So, a plot can belong to a single person or family. But it is under the tutelage of the whole clan that decisions to grant or not to grant to a third party are taken. (...) Thus, the land can be granted to the third party for many reasons: war damages, adoption, cooptation, etc."12

In the light of the above, it is obvious that land in Africa is an asset with a priceless value. That is why it has always been a source of conflict; preventing a community from owning it is often considered as subjecting it to slavery, because there is deep bond between the community and their land in unimaginable ways.

Taking all of this into account, it is obvious that granting a plot of land in Africa would never be done without valid reasons. If that is the case, to which purposes would land be granted to a third person or party for the construction and exploitation of long term work like the dam? This grant is usually made through the ignorance of consequences which would occur and taxation of State authorities which promotes the national or majority's well-being, regardless of that of the riparian communities affected. This is because the project is most often cloaked in secrecy, to the extent that neither public authorities, nor investors generally dare to present the hidden side of the iceberg. Having been sold on the project based on a fictitious motive of charity which promotes development, the residents become aware of the reality from the moment the project begins. ${ }^{13}$ From the start, they notice that even the so-called associated measures to their benefit, a result of the waiver of customary rights on the granted land, were undervalued. From that moment, the negative impact made up of risks and damages on the safety perimeter, prohibits public access (concessionaries) during and after the completion of the project. This is how the issue of riparian rights around hydroelectric dams in Cameroon arises.

\section{RIGHTS AND DUTIES OF RIPARIAN POPULATIONS AROUND HYDROELECTRIC DAMS IN CAMEROON}

\section{Riparian's Duties}

In a game of interest, the rights of one side are always the duties of the other side. To this effect, the only way for stakeholders to claim their interests and their rights is to recognize their duty and fulfil their commitments. Therefore, riparian populations should ${ }^{14}$ :

- Take into consideration all the lessons learned about nature protection.

- Protect absolutely the investment of the third party as a public heritage and observe bans on safety perimeter violation

- Comply with the concession agreement or waiver of customary rights on the granted site until its termination.

- Be conscious of damage caused by the violations of the respect for safety perimeters, and of the risks taken by practicing prohibited activities within this safety perimeter.

\footnotetext{
12 Bata Mbem, P., (2012, May 17), 74 years old, Mbombog (Patriarch) and former bank employee, Bikoukound.

${ }^{13}$ Colchester, M., and Forest Peoples Programme, (2000), Dams, Indigenous People and Vulnerable Ethnic Minorities, thematic study I.2 of the WDC, p. 30.

${ }^{14}$ Bartolome, L.J., de Wet, C., Mander, H., and Nagaraj, V.K., (2000), Displacement, Resettlement, Rehabilitation, Reparation and Development, thematic study I.3 of the WDC, p. 9.
} 
- Ban residents from using generators under electrical transmission and distribution lines without prior approval of the operator.

However, riparian populations do not only have duties. They also have rights which must be respected and should represent sometimes the duties of others.

\section{Citizens' Rights to Compensation}

General rights in this process are those which concern riparian populations and any person who suffers damage within a specified area. These rights are not affected by social status. They include:

- Being connected to the electrical distribution network.

- Promoting endogenous development through reduction of exports of our raw materials which, because of the lack of means to process them in the local community, would take another destination, not as finished goods or semi-finished products as required.

- Protecting consumer rights. That is, preserving citizens from damage which can be caused by supply of poor quality electrical energy. ${ }^{15}$

- Damage due to untimely power cuts made without at least 24 hours' notice ahead of time, or accidents due to lack of safety around hydroelectric facilities, transformer stations, and power lines.

However, consumers are not the only people who can benefit from State consideration. They can also be forced to pay the same damages if they spoil construction or expropriate material of hydroelectric dams. Examples include theft of electrical transmission and distribution cables, electricity poles, and so on. If facts are established when authorities concerned have reported it, people concerned are required to pay, not only for the damages to the operator, but also the evaluated material. Moreover, if unauthorized people succeed in entering a production plant or transformer station, interrupt power transmission, or cut distribution cables, they must not only pay the damages to the operator, but they will also be sued. In addition to general laws affecting all consumers, there are individual rights restricted to the residents.

\section{Particular or Especial Rights to Riparian defined by WDC}

In relation to the proximity of hydroelectric works, riparian populations should benefit from a number of advantages equal to the risks taken in the event of damage. Unfortunately, that is not usually the case in Cameroon. This is because even the compensation related to their exclusion from the occupied sites are often treated as a favor, added to their under-evaluation. A witness emphasized that: "In Edea and Song Loulou for instance, these so-called damages were mainly made up of direct consumption goods (bags of rice and cod, whisky, red wine, cans, tomato boxes, tobacco, pipes, boxes of matches, some makeshift loincloths, etc.) and the large part was used to be sacrificed for the marine spirits who had to bless and protect them during and after the works." ${ }^{16}$ If the landowner becomes a stakeholder in the project, it is thanks to the granted site under arbitration

\footnotetext{
${ }^{15}$ Bartolome, L.J., et al., (2000), Displacement, Resettlement, Rehabilitation, Reparation and Development, thematic study I.3 of the WDC, pp. 12-14.

${ }^{16}$ Loga, S., (2011, October 22), 86 years old, retired clerk in ALUCAM, Edea.
} 
of the public authorities in several forms: direct purchase, hire purchase, renting, direct actions, indirect and non-evaluated actions, etc. ${ }^{17}$

Furthermore, these damages, due to the grant of the land by landowners are not the only rights; there are also damages reserved for riparian landowners resulting from the loss of connection with their living environment, their investment, or their displacement from that site to another one. Therefore, as the safety perimeter is identified, they are banned to come back for any reason to the site for any activity either individually or collectively.

The evaluation and payment of compensation to riparian must always be accompanied by the putting in place of some structures for the social and economic reintegration of the underprivileged and damaged social sections of the population. For instance, structures ${ }^{18}$ such as communication, health, education, sports, social production, and Common Initiatives Group (CIG) buildings can be constructed. This will also involve public education and partnership for nature preservation with Non-Governmental Organizations (NGOs) working in that domain in order to meet the OM on environment. This is the focus of organizations such as Plan Cameroon, Worldwide Fund for Nature (WWF), International Union for the Conservation of the Nature (IUCN), and "Deutsche Gesellschaft fur Technische Zusammenarbeit" (GTZ). The establishment of these structures will contribute to the fight against deforestation and poaching, preservation of biodiversity and ecosystem balance, climate change prevention, protection of rare species, and especially endangered species, among others.

Added to individual rights recognized by national laws, the World Dams Commission (WDC) presents seven strategic priorities which come directly from the WDC report. No change has been done to date. Each strategic priority has a key message and a basis for action which underlies it. Each of these bases for action is described in detail in the WDC report as follows:

1. Get public acceptance: to guarantee a fair and sustainable development of hydraulic and energy resources, it is essential that the public accepts the key decisions. This acceptance comes from rights recognition, taking into account risks and protection of interests of all groups involved, namely the indigenous and tribal populations, women, and other vulnerable groups. The decision-making process and mechanisms must allow the participation of any group, and result in a demonstrable adherence to key decisions.

2. Complete evaluation of options: alternative solutions to dams often do exist. In order to study them, the need for water, food, and energy must be evaluated and goals clearly defined. The appropriate development action is defined from the range of the conceivable options. The choice is based on a complete and participative evaluation of all the political, institutional and technical options. During the process, social and environmental aspects have the same importance as the economic and financial factors.

3. Existing dams: it is possible to optimize advantages provided by several existing dams, talk about pending social problems and reinforce protective measures and re-establish the environment. Dams and the context in which they are exploited are not static over time.

\footnotetext{
${ }^{17}$ Berkamp, G., McCartney, M., Dugan, P., McNeely, J., and Acreman, M., (2000), Dams, Ecosystem Functions and Environmental Restoration, thematic study II. 1 of the WDC, p. 16.

${ }_{18}$ Adams, W., (2000), The Social Impacts of Large Dams: Equity and Distributional Issues, thematic study I.1 of the WDC, p. 3.
} 
Advantages and impacts can be modified by changes in priorities concerning the use of water, physical changes, and new land exploitation in the watershed, technological processes and evolution in the government policy through laws on environment, safety as well as economic and technical aspects.

4. Preservation of watercourses and means of subsistence: watercourses, watersheds and aquatic ecosystems are the biological driving force of the planet. They are sources of life and subsistence base of local communities. Dams transform the landscape and can have irreversible impacts. Understanding, protecting, and re-establishing watershed ecosystems is vital in promoting fair human development and guaranteeing the well-being of all species. The evaluation of the options and the decision-making related to improvement of watercourses must prioritize impact prevention, reduction, and the attenuation of adverse effects on the health and integrity of river systems.

5. Recognition of the rights and sharing of advantages: negotiations with affected people lead to mitigated measures of consequences and development, mutually agreed and legally enforceable. These recognize to the affected people the rights which improve their means of subsistence and their living conditions. Mitigation measures, re-establishment, and development are the responsibility of the State and the project promoter. They should prove to the people involved that abandoning their resources and current environment will improve their living conditions.

6. Guarantee standards implementation: This is to benefit the confidence of the public, governments, promoters, arbitration bodies, and operators shall respect all commitments related to planning, construction, and exploitation of dams. The respect of applicable regulations, criteria, and code of conduct, as well as negotiated agreement are guaranteed at any important level of the project planning and completion. A set of mutually reinforcing motivations and mechanisms must be put in place concerning social, environmental, and technical measures. A balanced association of regulatory and nonregulatory measures, comprising motivations and penalties is critical.

7. Sharing of watercourse for peace, development and safety: storage and deviating crossborder rivers' water lead to intense tensions between countries and inside the country. Dams which aimed at deviating water require a constructive cooperation. That is why the use and exploitation of resources are more and more subjected to agreements between States which are concerned with the promotion of regional cooperation and peaceful collaboration. Consequently, the close approach of providing a limited resource is replaced by watercourses sharing, and their related advantages, a process in which States use innovative method to define task scale and range. ${ }^{19}$

\section{PROCEDURES AND INFRINGEMENTS}

The recognition of riparian rights are sometimes presented as a magnanimous act, in addition to the under-evaluation of compensations paid to riparian communities by investors and public authorities. Sometimes, it is also noticed that if all this happens, it is because there is not a real and clear set of specifications which shall be used by the various stakeholders. ${ }^{20}$ Therefore, we are

\footnotetext{
${ }^{19}$ Imhof, A., Wong, S., and Bosshard, P., (2010), Citizen guide for the World Committee of Dams, p. 51.

${ }^{20}$ Dubash, N.K., Kothari, S., and Lissu, T., A Watershed in Global Convenance? An Independent Assessment of the World Commission on Dams, World Resources Institute, Lokayan and Lawyers' Environmental Action Team, Washington, D.C., p. 31.
} 
facing a double standard situation in which there are rights on one side, and duties on the other. That it is what one sadly notices, up to now, in the case of hydroelectric dams which are already in existence (i.e. Edea, Song Loulou and Lagdo). Strangely, in the first two cases, damages were paid to other ethnic groups, rather than to real beneficiaries. Furthermore, when redressing the damage suffered, the Bokok area, situated along the Sanaga River, was once more forgotten and disadvantaged, as in the Song Loulou case.

It was necessary to initiate a judicial procedure to start receiving tax benefits from incomes generated by the hydroelectric power plant of Song Loulou. The worst problem is that singleparent families headed by a woman (widow or unmarried), were not taken into account, given that women and minors did not take part in the debate. This illustrates that even from inside the group of beneficiaries, some restrictions created a kind of exclusion among the affected population. In Edea, these negotiations were also more selective because only investors were allowed to be part of negotiations, the colonial master and traditional authorities representing the different social stratum without knowing the ins-and-outs of negotiations, for which they were only dupes, seeking only the signature from local people in order to justify the legality of documents if they were needed. Knowing that the land had a social and non-commercial value, they considered traditional chiefs as the hierarchy of that society, as a way to achieve their goals, which consisted of acquiring or granting the solicited site. But if this level of disagreement was reached, it was because of three factors that were not considered but which represented the interests of the various stakeholders:

- Reckless pursuit of material interests by investors.

- Search of the local developmental baseline in colonies by the colonial masters.

- Ignorance of the populations and traditional authorities who were already convinced by colonial masters. $^{21}$

In the developing countries generally and in Cameroon specifically, investment procedures are constantly infringed upon. It may easily be concluded that these procedures are done in reverse of the normal standard. Instead of first compensating the dispossessed upon the granting of the site and before their expulsion, and then breaking ground, they expel the civilians first, and begin construction, which is supposed to be the last step. These damages are usually paid back as if they were donations, without taking into consideration the social and economic situation. As the construction site ends, commitments made to disposed riparian populations are reneged upon, and the people's rights are trampled. Unfortunately, this has been the case in Edea, Song Loulou or Lagdo.

Fortunately, now, with the new hydroelectric dams of Lom Pangar, Memve'ele and Mekin which are under construction, we have seen that the procedure for damages paid to beneficiaries have been going on smoothly. But, we are also aware that there is under-evaluation of what should actually be given to the affected population. There is, for instance, exclusion of people from the construction site of the hydroelectric dams of Mekin. As one victim reports "the evaluation of our goods was done on the basis of amortization, mainly as far as real estate is concerned, by taking into account spending done sometimes before the economic crisis of the 1990s. This was with the complicity of traditional and administrative authorities who were simply guessing when

${ }^{21}$ Dams and Development: A New Framework for Decision-Making, (2000), Earthscan Publications Ltd., p. 7. 
investments were made to deduce the amortization. They just considered the net value to be paid that day and this was not based on any rational criteria." 22

Although there has been a noticeable improvement in the area, there are still many infringements on the rights of the riparian populations of Cameroon.

\section{CONCLUSION}

In a nutshell, the issue of riparian rights and duties around hydroelectric dams in Cameroon since the construction of the first hydroelectric power plant of Edea (Edea I) between 1949 and 1953 has remained a problem. The riparian populations were not adequately compensated, neither were their real interests taken into consideration by the colonial master, France. Today this problem has continued because of infringement from several parties. There is usually an abandonment of responsibilities promised to the riparian settlements by the public authorities. They are neither able to determine real specifications, nor are they able to respect the so-called existing provisions. Furthermore, they are also unable to clarify the role of many managerial, developmental, or regulatory bodies that were created to handle any problems that emerge from the construction of hydro-electric dams. This carelessness leads today to the debate on riparian rights around the hydroelectric dams in Cameroon. Poor residents have been abandoned to look after themselves. There has also been a violation of their rights and their extreme poverty. At best, they have been given assistance as if it is charity, even when many of the inhabitants suffer from illnesses such as river blindness and onchocerciasis, caused by the heavy investment in energy. Finally, they are prevented from doing their work because of the production of energy which they do not benefit from.

\section{REFERENCES}

Bata Mbem, P., (2012, May 24), 83 years old, Mbombog (Patriarch) and former bank employee, Bikoukound.

Eloundou, S., (2012, June 12), 54 years old, Peasant and PASEM beneficiary, Nyabizan.

Loga, S., (2011, October 11), 86 years old, clerk of retirement works in ALUCAM, Edea.

Abdelmalki, L., et Mundler, P., (1995), Economie du développement, Paris, Hachette Supérieur. Adams, W., (2000), The Social Impacts of Large Dams: Equity and Distributional Issues, thematic study of WDC, I.1.

Amin, S., Faire, A., et Malkin, D., L'industrialisation et l'avenir de l'Afrique, Document préparé pour la Conférence Panafricaine sur les Stratégies pour le Futur de l'Afrique,Dakar, 1977

Bartolome, L.J., de Wet, C., Mander H., et V. K. Nagaraj, (2000), Displacement, Resettlement, Rehabilitation, Reparation and Development, thematic study of WDC, I.3.

Berkamp, G., McCartney, M., Dugan, P., McNeely, J., and Acreman, M., (2000), Dams, Ecosystem Functions and Environmental Restoration, thematic study of WDC, II.1

Colchester, M., and Forest Peoples Programme, (2000), Dams, Indigenous People and Vulnerable Ethnic Minorities, thematic study of WDC, I.2.

Dams and Development: A New Framework for Decision-Making, (2000), Earthscan Publications Ltd.

Dams and Development: An Overview, (2000), Raport of WDC

${ }^{22}$ Eloundou, S., (2012, June 12), 54 years old, Peasant and beneficiary of PASEM, Nyabizan. 
Dubash, N.K., Dupar, M., Kothari, S., and Lissu, T., (2001), A Watershed in Global Convenance? An Independent Assessment of the World Commission on Dams, World Ressources Institute, Lokayan and Lawyers' Environmental Action Team, Washington, D.C.

Imhof, A., Wong, S., and Bosshard, P., (2010), Citizen Guide for the World Committee of Dams International Rivers Network, PowerPoint presentation realized by the WDC.

International Rivers Network, (2000), Summary Excerpts from the World Commission on Dams Final Report.

Johnston, B.R., (2000), Reparations and the Right to Remedy, abstract of article which explain the legal bases of reparations.

Mbonji, Edjenguèlè, (1988), Les cultures de développement en Afrique : Essai sur l'impossible développement sans révolution culturelle, Yaoundé, Osiris-Africa.

McCully, P., (2001), Silenced Rivers: The Ecology and Politics of Large Dams, second edition, Zed Books, Londres.

Pottinger, L., International Rivers Network, and Berkeley, (1999), River Keepers Handbook: A Guide to Protecting Rivers and Catchments in Southern Africa.

Rangachari, R., Sengupta, N., Iyer, R.R., Banerji, P. and Singh, S., (2000), Large Dams: India's Experience, case study of WDC.

Sadler, B., Verocai, I., and Vanclay, F., (2000), Environmental and Social Impact Assessment for Large Dams, thematic study of WDC, V.2.

WDC, Represas y Desarrollo: Un Nuevo Marco para la Toma de Decisiones, the official report. Wiehen M. H., and Transparence International, (1999), Transparency and Corruption on Building Large Dams, thematic study of WDC, V.4. 